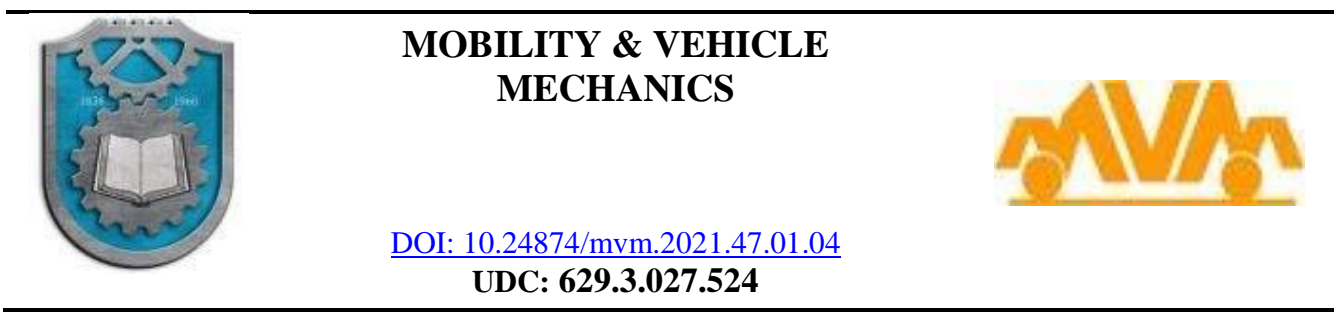

\title{
WHEEL OF VEHICLE INCREASED SURVIVABILITY
}

Liubov Sladkova ${ }^{1} *$

Received in July $2020 \quad$ Revised in August $2020 \quad$ Accepted in September 2020

RESEARCH ARTICLE

ABSTRACT: The article, based on the analysis of technical solutions of tyres of various kinds, proposes a fundamentally new constructive performance of high-traffic and survivability tires. The design and operation of the bus is described. The proposed design is theoretically and experimentally justified. Based on the experimental studies of the interaction of the pneumatic tyre with the road surface, the process of traction-clutch characteristics of the airwheeled engine with the ground is simulated. Experimental studies of the pneumatic engine allowed to assess its performance on roads of different condition, depending on the mass and changes in pressure in the event of damage to flexible elements of the wheel. The resulting indicators allow to sufficiently assess not only the survivability of the wheel, its geometric characteristics, but also to describe the physical nature of the interaction of the engine with the road surface, and to confirm the results of theoretical studies. Practical recommendations are given to determine the rational parameters of the tyre of the proposed design. The design of the pneumatic wheel will expand the technological capabilities of the base machine and use it more widely in extreme conditions. The provision of high traffic vehicles proposed in the article pneumatic wheels is conditioned by the need: in the transportation of heavy large cargoes with the exception of separate transportation processes and the subsequent assembly of components.

KEY WORDS: pneumatic wheel (tyre), design, experiment, passability, survivability, contact spot

(C) 2021 Published by University of Kragujevac, Faculty of Engineering

${ }^{1}$ Lyubov Sladkoval Moscow, Russia. Russian University of Transport. Moscow, 9 Obraztsova Street, b.9.127994, rich.cat2012@yandex.ru 


\section{TOČAK VOZILA POVEĆANE IZDRŽLJIVOSTI}

REZIME: Ovaj rad je baziran na analizi tehničkih rešenja pneumatika različitih vrsta i predlažu se nove konstruktivne performanse pneumatika sa dugim radnim vekom $\mathrm{i}$ izdržljivosti. Analiza dizajna i operabilnosti je urađena za pneumatike autobusa. Predloženi dizajn je teorijski i eksperimentalno opravdan. Na osnovu eksperimentalnih studija interakcije pneumatika i podloge, simulira se proces uključivanja spojnice i sprega motora $i$ sistema kretača sa podlogom. Eksperimentalne studije omogućile su da se procene performanse na putevima različitog stanja, u zavisnosti od mase i promene pritiska u slučaju oštećenja fleksibilnih elemenata točka. Dobijeni indikatori omogućavaju da se u dovoljnoj meri proceni ne samo održivost točka, njegove geometrijske karakteristike, već i da se opiše fizička priroda interakcije točka sa površinom puta $\mathrm{i}$ da se potvrde rezultati teorijskih studija. Daju se praktične preporuke za određivanje racionalnih parametara pneumatika predloženog dizajna. Dizajn pneumatskog točka proširiće tehnološke mogućnosti baznog vozila i može se koristiti u ekstremnim uslovima eksploatacije. Opremanje vozila koja se intenzivno koriste $\mathrm{u}$ transportu pneumaticima prikazanim u radu je uslovljeno potrebom za prevozom teških velikih tereta sa izuzetkom odvojenih procesa prevoza i naknadnog sklapanja komponenata.

KLJUČNE REČI: pneumatski točak (guma), dizajn, eksperiment, prohodnost, izdržljivost, zona kontakta 


\section{WHEEL OF VEHICLE INCREASED SURVIVABILITY}

\section{Liubov Sladkova}

\section{INTRODUCTION}

Problems related to the level of support traversability occur when moving vehicles on an uneven road, and solutions that have bumps and potholes. This involves the risk of a tyre being broken or one of the car's wheels entering a pothole, diverting it and risking an accident. The provision of high-traffic vehicles with air wheels is conditioned by the need to transport heavy large and special goods when working in areas remote from civilization. The introduction of the developed wheel will reduce the cost of refurbishing existing vehicles and reduce them for the production of new vehicles that meet modern security requirements. To solve the problem of modernization of the pneum-wheeled engine of the vehicle, the method of systemic search for a solution on the materials of scientific and technical literature was used, methods of calculating the strength and assessment of economic performance indicators of the modernized pneumoper [1-3].

The goal is to modernize the air-wheeled engine of a high-traffic vehicle is the ability to operate vehicles in extreme conditions in the winter and summer season and the ability to continue driving after the wheel break. The use of a pneumatic engine for special purpose vehicles, which allows to preserve the operational properties of the machine, while maintaining a minimum pressure in the tire, depending on the extent of its damage in various road conditions is relevant and meets the requirements of the federal target program "Research and development on priority areas of development of the scientific and technological complex of Russia for 2007-2015

\section{ANALYSIS OF THE DEVELOPMENT OF PNEUMO-WHEELED ENGINES AT THE CURRENT STAGE}

One of the main elements of ensuring the durability, mobility and traversability of wheeled vehicles are tires, which are the main element of the wheel engine. Their classification features include the form of a section: traditional (toroid), wide-profile, arched, pneumococcal, large tires, top-balloon tires.

The main ways to improve tyre safety are divided into two groups [4-6]:

- $\quad$ ensuring that the car is short-lived on a damaged bus;

- $\quad$ ensuring long-term movement of the car on a damaged tire.

The first group includes: cameraless tyres equipped with various sealing compositions; Tires with special spongy layers on the inner cavity; Multi-layered tyres; tires with elastic filler of the inner cavity; tires with rubber-metal inserts. The second group of designs of safe tire, can be attributed tires with special inserts - rims of magnesium or aluminium alloys. Modern combat wheels and military vehicles have been widely used with combat-resistant wheels with cameraless pneumatic tyres, capable of maintaining their functions in the face of through damage from the mechanical action of bullets or pellets of small arms, fragments of artillery shells and striking factors of anti-vehicle mines or grenades [7, 8]. 


\section{TIRE DESIGN AND OPERATION}

The purpose of the tire upgrade is to improve the survivability and reliability of the tyre when driving with the maximum allowable low pressure, which is possible if the tyre integrity is violated during the job.

The existing chamber-type pneumatic tyre (Figure 1. a, b) contains a tire that is not conventionally shown, and an inflatable camera 1 , which is pressurized by air, creating the required pressure in the tires. The disadvantage of this design is that in the case of violation of the integrity of the camera there is a reduction in pressure, leading to the inability of the latter to move on the surface of the road. To eliminate this shortcoming, we are offered a camera (Figure 1, a, b), consisting of separate contact cells 2, made in the form of lengthy cavities and filling all chamber space. At the same time, the length of each cell is 2 at least the length of the chamber's internal surface 1 on its longitudinal section. In order to maintain the required pressure, each cell 2 is subject to a separate pressure supply.

Each cell, made in the form of a cavity, contains a reverse valve 3 and has its own output of 4 on the main nipple 5 .

Cell 2 location can be concentric relative to another (Figure 1, a), or spiral in the radial direction relative to the outer limiting path 1 in which these cells are located (Figure 1). Also, cells 2, made in the form of separate cavities can be twisted at an angle relative to each other. The problem is solved by the fact that in the famous design on Figure 1 - cavities are twisted at an angle to each other.

In the proposed pneumatic tyre design, lengthy cavities can be replaced by spherical cavities. Such a constructive solution will allow to maintain a more stable pressure in the event of a break out of the wheel. However, such a constructive solution has significant drawbacks if it is necessary to apply pressure to each cavity autonomously. The proposed pneumatic tyre design with long cavities is made and works as follows.
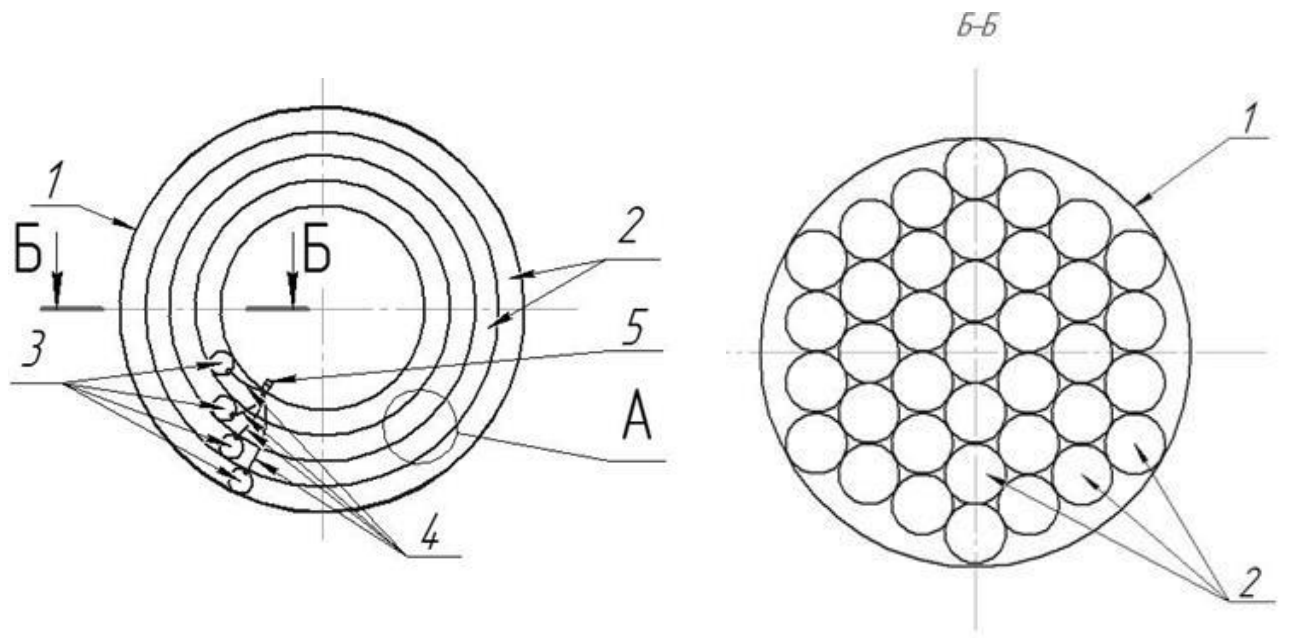

Figure 1 Pneumatic tyre of the proposed design: $a$ - the location inside the camera; $b$ - by section of the Tires

The inner surface of the tyre 1 (Figure $1 \mathrm{a}, \mathrm{b}$ ) is filled with separate contact cells 2 , made in the form of lengthy cavities, such as tubular, rectangular, etc. closed section, or the tire is 
made by casting with simultaneous formation in its inner cavity of these cells 2 . To ensure the assembly of the tyre, the 1 length of each cell 2 must be at least the 232 length of the tyre forming the inner surface of the tyre 1 on its longitudinal section. To ensure the battery life of the 2 cells, each of them is subject to a separate pressure supply through reverse valves 3 with its own outputs of 4 to the main nipple 5. After creating pressure in Cell 2, they are pressed against the inside of tire 1, and, touching their walls, are pressed against each other. At the same time, each cell 2 can be located concentrically relative to the other (Figure 1, a), or spiralin the radial direction relative to the outer limiting contour of tire 1, in which these cells 2 are located. Cell 2, made in the form of cavities, can be twisted at an angle relative to each other, similar to the execution of a rope swirl. The minimum number of cells is two.

The pressure in each cell 2 is fed through nipple 5. In the case of tyre damage, only part of the cells are damaged, while the rest continue to operate thanks to the autonomous pressure liner and the presence of a reverse valve 3 on each cell 2 . The pressure in undamaged cells 2 remains sufficient to keep the tyre 1 healthy and maintain its profile.This solution will improve the survivability and reliability of 1 tyre when the breakdown of any of the cells 2 .

Options for laying cells in a tire does not have a significant impact on its traction-clutch characteristics.

The size of the flexible wheel (cells) was chosen on the basis of statistical analysis of wheel parameters for different types of cars. It has been established that the geometric characteristics of the wheel (the diameter and width of the tire) vary in close correlation. The weight of the wheels in 6 cases out of 22 has an "outlier." Therefore, when selecting model parameters for theoretical and experimental studies, it is possible to extend the values obtained for the study version to other known models without introducing any corrective factors on the type of tyres used. It has been established that the change in the deformation of the tire is not linear, but hyperbolic in nature and changes in the form of vectors of changes in gravity, vibrations of the machine, rigidity and elasticity of the wheel. The higher the rigidity and plasticity of the wheel, the smaller the size will occur joint deformation of the wheel and road.

\section{EXPERIMENTAL STUDIES OF THE INTERACTION OF PNEUMATIC TYRES WITH THE ROAD SURFACE}

The purpose of experimental research is to study the processes of interaction of the pneumatic wheel of the proposed design with the road during its direct movement. Given the directness of the movement of the machine, during the experiment will be considered the rolling of a single wheel on the surface of the road of different states. The process of researching the upgraded pneumatic wheel in straight motion in start-up and braking modes consists of two stages. The first is logical, which explores the mechanism of interaction of the pneumatic wheel with the road surface and determines the choice of restrictions imposed. The second stage is the laboratory. The experiment was conducted in three variants on dry - A, wet sand - B and on solid coating - C depending on the mass of X1 and pressure in the wheel $\mathrm{X} 2$. according to the planning matrix. The results of the experiment were evaluated by a 3D change in the contact spot ( $\mathrm{a}$ and $\mathrm{b}$, the depth of the $\mathrm{H}$ wheel dive) in the form of $\mathrm{P}=\mathrm{f}(\mathrm{a}, \mathrm{b}, \mathrm{H})$ functionality.

Before the experiment, the density of the soil was determined during the experiment, on the solid coating it was 0.98 , on the loose sand $1440 \mathrm{~kg} / \mathrm{m} 3$, on the wet sand $1920 \mathrm{~kg} / \mathrm{m} 3$. The variability of ground density in each series of experiments did not exceed $4.7 \%$, which is 
permissible, as such a change in density within these limits does not have a significant impact on the traction-chain characteristics of the ground. A large percentage of the error will lead to change in the physical process on the modes of acceleration and braking of the wheel.

Given the parameters of the wheel-ground modeling system, the boundaries of the input parameters will be inversely proportional to the limits of the original parameters and the scale of the simulation. The results of the definition of the boundaries of research on the model are presented in Table 1.

Table 1 Limits of Research on Model

\begin{tabular}{|l|c|c|c|}
\hline \multirow{2}{*}{ Option name } & \multirow{2}{*}{ Symbol } & \multicolumn{2}{|c|}{ Border } \\
\cline { 3 - 4 } & & Maximum value & Minimum value \\
\hline Pressure in the wheel, $X_{1}, \mathrm{~Pa}$ & $p$ & 101325 & 202650 \\
\hline Weight of the wheel, $X_{2}, \mathrm{~kg}$ & $m$ & 50 & 100 \\
\hline
\end{tabular}

The results allow us to assess the performance of the proposed pneumatic wheel design in the event of a breakdown of one of the elements of the wheel. In addition, the experiment will describe the physical nature of the interaction of the proposed PC with the road surface.

The input parameters (factors to be investigated) are the parameters that characterize the condition of the pneumatic wheel when moving it along the road: the weight of the $\mathrm{m}$ wheel; Pressure in the $\mathrm{p}$ wheel; the condition of the road (loose, loose, hard cover); modes of movement (established movement, acceleration, braking, time for this process 233and the length of the braking path). Weekends - a spot of contact and the depth of the wheel's immersion in soft ground.

In the experiment, a self-propelled dynamometric trolley with an adjustable rev frequency was used to move the wheel and create the necessary traction. To control the change in the parameters of the contact spot above the wheel, a camera was rigidly fixed, allowing to record its change from the same height on different modes of operation of the machine (rest, acceleration, braking are brought to Figure 1) on the model of the road of different state.

During acceleration (Figure 2, b) at the very beginning of this process on the imprint of the tread (contact spot) there is a detachment of soil particles with the formation of a kind of burtic. Moreover, the depth of the contact spot in this place is greater than on the rest of the way of the machine. A similar phenomenon is observed in the process of braking the car (Figure 2, a). In both cases, the rear of the wheel or in front of it is formed a shift shaving of the ground.

During acceleration (Figure 2, b) at the very beginning of this process on the imprint of the tread (contact spot) there is a detachment of soil particles with the formation of a kind of burtic. Moreover, the depth of the contact spot in this place is greater than on the rest of the way of the machine. A similar phenomenon is observed in the process of braking the car (Figure 2, a). In both cases, the rear of the wheel or in front of it is formed a shift shaving of the ground. 

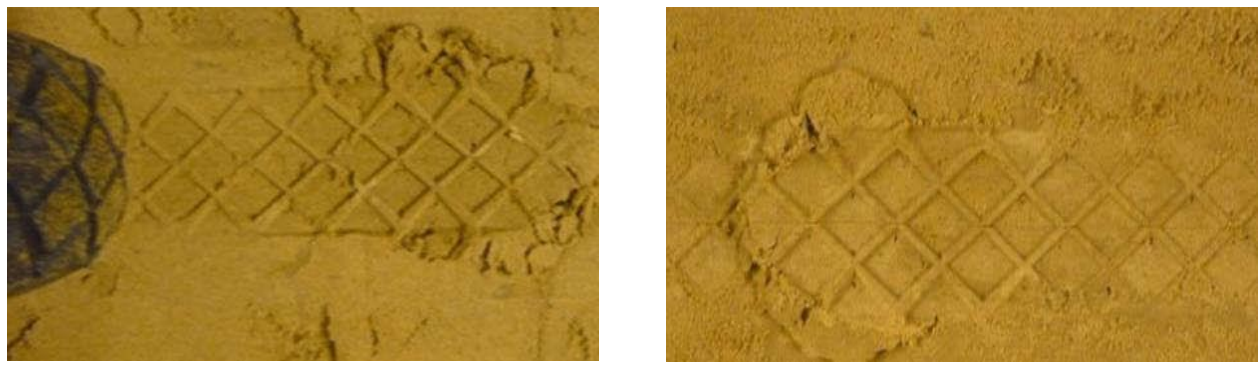

Figure 1 Interaction of the tyre with the ground (wet sand): a braking process; $b$ - the process of dispersal

The reason for this is the shift of the forces of the clutch of soil particles with the surface of the tire in the direction, directed in the opposite direction of the machine, comparable to the inertial force acting on the machine in the mode of unidentified motion. The physical nature of the change in the depth of the imprint lies in the difference in the speeds of the rotating wheel and soil particles at the moment of braking and touching from the place. In the first case, the ground particles in contact with the wheel have a speed commensurate with the circular speed of the wheel, so when braking they throw forward, forming a drill in front in the course of movement. In the process of acceleration, on the contrary, the wheel begins to gain speed, giving the stationary particles of the ground a commensurate speed, throws the particles back, forming a drill behind itself. In the mode of established movement, the tread print is even lye for the entire length of the car.

The test of the reproducibility of the experiments was carried out on the Cohron Criterion with a confidence probability of 0.95 .

The results of the experiment are presented in the form of regression dependence of the species [9]:

$$
y=b_{0} x_{1}+b_{1} x_{1}+b_{12} x_{1} x_{2}
$$

The significance of the regression equation (Table 2) was assessed by the Trident criterion, and adequacy by Fisher's criterion with a confidence probability of 0.95 .

Using the values of the regression coefficients for Option A (Table 1), we will build regression models that will be put together in Table 3 .

During the experiment, it was found that on dry and wet sand, which in fact represent the interaction of the hard wheel and the base, the X1 factor (change in pressure p) has a direct effect only on the change in performance during the experiment on variant $\mathrm{A}$. The mass of the machine has a significant impact only on the change of the large axis of the ellipse. On the wet sand there is a joint effect of pressure in the tire and the mass of the machine in the modes of acceleration and braking.

On the hard coating, the mutual influence of factors is excluded, as is the X1 pressure factor in the wheel. Experimental studies of the pneumatic engine allowed to assess its performance on roads of different condition, depending on the mass and changes in pressure in the event of damage to flexible elements of the wheel. The resulting indicators allow to sufficiently assess not only the survivability of the wheel, its geometric characteristics, but also to describe the physical nature of the interaction of the engine with the road surface, and to confirm the results of theoretical studies. 
Table 2 Values of regression equation sand ratios

\begin{tabular}{|c|c|c|c|c|c|c|c|c|c|c|}
\hline \multirow{2}{*}{$\begin{array}{c}\text { Regression } \\
\text { equation } \\
\text { ratio }\end{array}$} & \multicolumn{7}{|c|}{$\begin{array}{c}y_{1} \sim a- \\
\text { large diagonal of the } \\
\text { ellipse }\end{array}$} & $\begin{array}{c}\text { The parameter under investigation } \\
\text { small diagonal of the } \\
\text { ellipse }\end{array}$ & \multicolumn{3}{c|}{$\begin{array}{c}y_{3} \sim H- \\
\text { print depth }\end{array}$} \\
\cline { 2 - 10 } & 1 & 2 & 3 & 1 & 2 & 3 & 1 & 2 & 3 \\
\hline$b_{0}$ & 14.49 & 18.49 & 17.96 & 7.8 & 8.6 & 8.8 & 1.49 & 3.52 & 3.28 \\
\hline$b_{1}$ & -0.84 & -1.00 & -1.14 & -0.32 & -0.21 & -0.4 & -1.17 & -0.01 & 0.10 \\
\hline$b_{2}$ & -0.16 & 0.67 & 0.23 & 0.07 & 0,17 & 0,03 & 0,06 & $-0,48$ & $-0,44$ \\
\hline$b_{12}$ & &
\end{tabular}

It has been established that during the acceleration there is a detachment of soil particles with the formation of a kind of burtic, and the depth of the contact spot in this place is greater than on the rest of the way of movement of the machine. A similar phenomenon is observed in the process of braking the car. In both cases, the rear of the wheel or in front of it forms a shift shaving of the ground as a result of the shifting of the forces of the clutch of soil particles with the surface of the tire in the direction, directed opposite the direction of the machine, comparable to the inertial force acting on the machine in the mode of unaccumulated movement.

The physical nature of the change in the depth of the imprint lies in the difference in the speeds of the rotating wheel and soil particles at the moment of braking and touching from the place. In the first case, the ground particles in contact with the wheel have a speed commensurate with the circular speed of the wheel, so when braking they throw forward, forming a drill in front in the course of movement. In the process of acceleration, on the contrary, the wheel begins to gain speed, giving the stationary particles of the ground a commensurate speed, throws the particles back, forming a drill behind itself. These phenomena are not present at rest.

It has been established that the actual depth of the track is determined not only by the properties of the soil at the time of its interaction with the engine, but also by the loss of pressure in the pneumatic engine as a result of its damage.

In the vast majority of cases, the size of the print is influenced by the vertical component of the force on the wheel, i.e. the weight of the machine. The exception is an experiment on dry sand, where the size of a large diagonal depends on the pressure in the tire, and small from the mass. Moreover, the increase in pressure leads to a decrease in the size of the large diagonal, and the increase in mass to increase the small diagonal, the depth of the imprint during the experiment on dry sand and in the mode of unidentified movement when moving on dry sand depends on the mutual influence of mass and pressure, leading to a decrease in the depth of the imprint.

Table 3 Regression Equations for Different Versions of experiment - A

\begin{tabular}{|l|l|l|}
\hline No & Option for the experiment & Regression equation for contact spot \\
\hline & & Large diagonal of the ellipse \\
\hline
\end{tabular}




\begin{tabular}{|c|c|c|}
\hline 1 & \multirow{3}{*}{ Dry sand } & $a=14,85-0,84 x_{1}+0,91 x_{2}$ \\
\hline 2 & & $a=18,49-1,00 \mathrm{x}_{1}$ \\
\hline \multirow[t]{2}{*}{3} & & $a=17,96-1,14 \mathrm{x}_{1}$ \\
\hline & & Small diagonal of the ellipse \\
\hline 1 & \multirow{3}{*}{ Dry sand } & $b=7,80+0,45 x_{2}$ \\
\hline 2 & & $b=8,60+0,33 x_{2}$ \\
\hline \multirow[t]{2}{*}{3} & & $b=8,80+0,49 x_{2}$ \\
\hline & & Print depth \\
\hline 1 & \multirow{3}{*}{ Dry sand } & $H=1,49+0,28 x_{2}$ \\
\hline 2 & & $H=3,52-0,48 x_{1} x_{2}$ \\
\hline 3 & & $H=3,28-0,44 x_{1} x_{2}$ \\
\hline
\end{tabular}

When moving on wet sand, the depth of the print does not depend on changes in mass and pressure parameters, but only on the condition of the road. On wet sand in acceleration mode it is twice as high as at rest and braking, which is confirmed by the practice of driving cars when touching them from the place.

As a result of the tests conducted to select rational pressure, the equations of regression of distributions of normal pressures by the area of contact of the wheels of the vehicle under study with the supporting surface at different internal air pressures in the tyres have been obtained. The nomogram sections obtained allow a selection of rational parameters of the pneumo-wheeled engine.

The technique can be used in solving issues of forecasting the performance of cars being developed, improving the mobility of cars by rationally selecting the parameters of their wheeled engines with internal cavities.

\section{CONCLUSIONS}

As a result of the research carried out in this work, the actual technical task is to develop and justify the new rational design of the pneum-wheeled engine. Theoretical, experimental studies and calculations of the author made it possible to improve the efficiency of operation of cars with pneumo wheels, expressed in the most complete implementation of their performance in any conditions.

Mathematical description of the process of tire deformation when driving on the supporting surface at the specified values of the structural and operational parameters of the air-engine allows to determine the changes in the tyre's support ability depending on the pressure in the tyre and load. The use of pneumatic cameras provides the ability of the car to move when the car's tyre is damaged.

The use of wheels with pneumatic cameras will increase the rate of autonomy, passability and security, which in turn significantly increases the mobility of cars in critical conditions with damage to the wheel engine and allows you to continue driving. On serial wheels with tires when they are damaged and there is no excessive air pressure in them the car on deformed soils can not move independently.

\section{ACKNOWLEDGMENTS}

DYNAMICS AND INTELLIGENT SYSTEMS OF THE RIGHT TO THE WORLD DYNAMICS AND INTELLIGENT SYSTEMS OF THE MANAGEMENT (Tires) 
The solution method developed in the paper, based on free vortex design, involves the linking of meridional and blade-to-blade solutions. The method which employs a finite element techniques has been developed for determining the blade-to-blade flow of an incompressible non-viscous fluid through a rotating turbomachine blade row.

In accordance with Bauersfeld method, the design of impeller blades is performed in iterative manner by using relationships between velocity components and geometrical blade parameters. The applied procedure allows a very fast design of the blade of the hydrodynamic transmissions for the defined input data.

The presented method is shown in case of pump impeller blade, but with minor changes it can be used for the design of the turbine which is the second component of hydrodynamic torque converter.

\section{REFERENCES}

[1] GOST P 51893-2002. Pneumatic tires. General technical security requirements. - M.: Publishing Standards, 2002.

[2] GOST 5513-97. Pneumatic tires for trucks and trailers to them.

[3] GOST 8.207-76. Gos. a system for ensuring the unity of measurements.

[4] Efremov, A.V., Kukolev, D.N.: "Classification of Foreign Automotive Technology", Foreign military review, No. 8, 2007, pp. 34-42.

[5] Skotnikov, V.A., Ponomarev, A.V., Klimanov, A.V.: "Passage of machines", Minsk: Science and Technology, 1982, p. 328.

[6] Tractors, Part II. Theory: studying. Allowance for Universities / V.V. Guskov - Minsk: High School, 1988, p. 384.

[7] Naumov, A.N.: Assessment of the design and operational parameters of cars on the indicators of their supporting passability / A.N. Naumov. the author's abstract diss. Kand. Tech. Science: 05.05.03. M., 2008, p. 23.

[8] Bocharov, N.F.: Vehicles on highly elastic engines / N.F. Bocharov, V.I. Gusev, V.M. Semenov, etc. - M.: Mechanical engineering, 1974, p. 208.

[9] Sladkova, L.A., Ivanovsky, V.S.: Technical basics of creating machines. - Moskow, MTU, 2010, p. 295. 